\title{
Potential Effects of Alkaloid vindolicine Substances in Tapak Dara Leafs (Catharanthus roseus (L.) G. Don) in Reducing Blood Glucose Levels
}

\author{
Agung BS Satyarsa \\ Medical Education Study Program \\ Faculty of Medicine Udayana University Denpasar Bali \\ Jl. P.B. Sudirman, Denpasar, Bali \\ Email : abssatyarsa@student.unud.ac.id
}

\begin{abstract}
Diabetes mellitus is a degenerative disease that commonly found and related to an unhealthy lifestyle and genetic factors. Current management of diabetes mellitus includes control of blood sugar levels and prevention of complications. Recent studies found that many phytochemicals have the potential to control blood sugar levels in patients with diabetes. Alkaloid substances from leaves of Tapak Dara have an effect on decreasing blood glucose. This review article aims to describe the potential effects of the Alkaloid vindolicine from Tapak Dara leaves (Catharanthus Roseus L.) in reducing blood glucose levels in patients with type 2 diabetes mellitus. The activity of vindolicine alkaloid against $\beta$ cells in previous studies has shown to improve $\beta$ cells activity and induce insulin secretion thus preventing further hyperglycemia. In addition, the vindolicine alkaloid also has a role in activating pancreatic $\beta$ TC6 cells and carrying out an immediate reaction in blood vessels. As conclusion, further research is needed to prove the maximum effect of the utilization of tread leaf extract as well as the toxicity test to determine the toxic effects of the alkaloid substances in the tread leaf.
\end{abstract}

Keywords: Type 2 Diabetes Mellitus, Vindolicine Alkaloid, Tapak Dara, blood glucose levels 
Review Article

\title{
Potensi Efek Zat Alkaloid vindolicine dalam Daun Tapak Dara(Catharanthus roseus (L.) G. Don) dalam Menurunkan Kadar Glukosa Darah
}

\author{
Agung BS Satyarsa \\ Program Studi Pendidikan Dokter \\ Fakultas Kedokteran Universitas Udayana Denpasar Bali \\ Jl. P.B. Sudirman, Denpasar, Bali \\ Email : abssatyarsa@student.unud.ac.id
}

\begin{abstract}
Abstrak
Diabetes mellitus merupakan suatu penyakit degeneratif yang sering ditemukan akibat pola hidup kurang sehat dan faktor genetik. Upaya penatalaksanaan diabetes mellitus adalah dengan pengendalian kadar gula darah dan pencegahan komplikasi dari penyakit ini. Banyak studi terkini tentang bahan fitokimia yang memiliki potensi dalam pengendalian kadar gula darah pada pasien dengan diabetes. Efek zat alkaloid dari daun Tapak Dara saat ini mulai dipertimbangkan potensinya dalam menurunkan kadar gula darah. Tujuan penelahaan studi adalah menjelaskan potensi efek dari zat Alkaloid vindolicine dari daun Tapak Dara (Catharanthus Roseus L.) dalam menurunkan kadar glukosa darah pada penderita diabetes mellitus tipe 2. Dalam penelitian sebelumnya aktivitas Alkaloid vindolicine terhadap sel $\beta$ menunjukkan adanya perbaikan sel $\beta$ yang dapat menginduksi pembentukan insulin sehingga dapat menekan kondisi hiperglikemia. Alkaloid vindolicine juga memiliki peran dalam mengaktifasi sel $\beta$-TC6 pankreas dan melakukan reaksi langsung dalam pembuluh darah. Sebagai simpulan, perlu dilakukan penelitian lebih lanjut untuk membuktikan efek maksimum dari pemanfaatan ekstrak daun Tapak Dara serta uji toksisitas untuk mengetahui efek toksik dari zat alkaloid dalam daun Tapak Dara.
\end{abstract}

Kata kunci: Diabetes Mellitus Tipe 2, Alkaloid vindolicine, Daun Tapak Dara, Kadar Glukosa Darah 
Review Article

\section{Pendahuluan}

Kesehatan merupakan aspek yang sangat penting bagi kehidupan manusia. Saat ini banyak penyakit yang tidak disebabkan oleh kuman atau bakteri, tetapi disebabkan oleh kebiasaan atau pola hidup tidak sehat. ${ }^{1}$ Berbagai penyakit diderita mulai dari yang ringan sampai yang berat pada semua kalangan lanjut usia, contohnya; Diabetes Mellitus (DM), kanker, stroke, jantung, rematik, dan tekanan darah tinggi. Salah satu dari penyakit tersebut yang banyak diderita oleh lanjut usia yakni DM. ${ }^{2-4}$

DM merupakan suatu penyakit degeneratif yang sering diderita akibat pola hidup kurang sehat dan faktor genetik. Terdapat dua tipe penyakit diabetes di Indonesia yakni DM tipe 1 dan tipe $2 .{ }^{3}$ Pada Diabetes tipe 1 terjadi infeksi pada sel-sel $\beta$-pankreas (insulitis) oleh karena virus cocksakie, rubella, CMV, herpes dan lain-lain, yang menyebabkan terjadi reaksi antibodiantigen dalam sel beta yaitu ICA (Islet Cell Antibody) yang menyebabkan hancurnya sel beta. ${ }^{4}$ Hal ini biasanya terjadi sejak lahir, sehingga sering disebut Diabetes juvenille. Pada Diabetes tipe 2 produksi insulin bisa normal, kurang, malah berlebihan namun terjadi pengurangan reseptor insulin pada permukaan sel, sehingga insulin tidak dapat bekerja dengan maksimal (resistensi insulin). ${ }^{3,6}$

Menurut penelitian WHO (World Health Organization) tahun 2014, Indonesia masih berada di posisi ke empat sebagai negara dengan jumlah penduduk terbesar yang menderita penyakit DM setelah Amerika Serikat, China, dan India. ${ }^{1}$ Riset Kesehatan Dasar (Riskesdas) yang dilakukan pada tahun 2018 menemukan bahwa prevalensi nasional DM berdasarkan diagnosis dokter pada penduduk umur $>15$ tahun adalah 2,0\% dengan prevalensi tertinggi terdapat di Daerah Khusus Ibukota, Jakarta (3,4\%). 3,4

Mahalnya biaya pengobatan dan pola hidup yang kurang sehat menyebabkan penyakit ini semakin berkembang luas di masyarakat. ${ }^{7,8}$ Pengobatan alternatif untuk pasien yang banyak dikembangkan dewasa ini belum dapat menjamin kesembuhan untuk dikonsumsi oleh penderita DM tipe $2 .{ }^{9}$ Pada umumnya penyakit DM tipe 2 tidak diobati dengan pemberian hormon insulin yang berperan untuk mengontrol kadar gula dalam darah. Terdapat dampak negatif berupa efek samping jika pengobatan insulin dilakukan secara berlebihan. ${ }^{10,11}$

Berbagai instansi baik negeri maupun swasta saat ini telah banyak mengembangkan inovasi produk obat terbarukan untuk penyakit DM tipe 2 dengan cara mengolah produk herbal berdasarkan bukti ilmiah ataupun penelitian sebelumnya. Baik pengembangan di bidang bioteknologi seperti pembuatan insulin atau obat herbal dalam membantu mengkontrol kadar gula dalam darah. Telah banyak dilakukan penelitian dalam menunjang keberhasilan pengobatan terhadap penderita DM. ${ }^{11-15}$

Tanaman Tapak Dara adalah salah satu jenis tanaman hias yang umumnya terdapat di 


\section{Review Article}

daerah Tropis. ${ }^{16}$ Saat ini belum banyak masyarakat yang mengetahui tentang manfaat daun Tapak Dara sebagai obat herbal untuk diabetes. Daun Tapak Dara mengandung berbagai zat-zat antitoksin dan zat Alkaloid Biindole sepeti Zat Alkaloid vindolicine yang dapat digunakan pengobatan penyakit degeneratif salah satunya adalah DM Tipe 2. ${ }^{16-21}$ Pengolahan Daun Tapak Dara sebagai obat untuk diabetes belum dikembangkan secara luas. Tujuan penelaahan ini adalah untuk membahas potensi essensial dari ekstrak zat Alkaloid vindolicine dalam Daun Tapak Dara agar dapat memberi informasi yang diharapkan dapat menjadi obat komplementer dalam penatalaksanaan penyakit DM Tipe 2 .

\section{Diabetes Mellitus}

DM Tipe 2 merupakan tipe diabetes yang lebih banyak penderitanya dibandingkan dengan DM Tipe 1. ${ }^{1,2}$ Penderita DM Tipe 2 mencapai $90-95 \%$ dari keseluruhan populasi penderita diabetes, umumnya berusia di atas 45 tahun, tetapi akhir-akhir ini penderita DM Tipe 2 di kalangan remaja dan anak-anak populasinya meningkat. ${ }^{4}$ Etiologi DM Tipe 2 merupakan multifaktor yang belum sepenuhnya terungkap dengan jelas. Faktor genetik dan pengaruh lingkungan cukup besar dalam menyebabkan terjadinya DM tipe 2, antara lain obesitas, diet tinggi lemak dan rendah serat, serta kurang gerak badan. ${ }^{2,4}$

Berbeda dengan DM Tipe 1, pada penderita DM Tipe 2, terutama yang berada pada tahap awal, umumnya dapat dideteksi jumlah insulin yang cukup di dalam darahnya, selain kadar glukosa yang juga tinggi. ${ }^{1,4} \mathrm{Jadi}$, awal patofisiologis DM Tipe 2 bukan disebabkan oleh kurangnya sekresi insulin, tetapi karena sel-sel sasaran insulin gagal atau tak mampu merespon insulin secara normal. Keadaan ini dapat disebut sebagai resistensi insulin. Selain kejadian resistensi insulin, pada penderita DM Tipe 2 dapat juga timbul gangguan sekresi insulin dan produksi glukosa hepatik yang berlebihan. Namun demikian, tidak terjadi pengrusakan sel-sel $\beta$ Langerhans secara otoimun sebagaimana yang terjadi pada DM Tipe $10^{4,5}$

Sel-sel $\beta$ kelenjar pankreas mensekresi insulin dalam dua fase. Fase pertama sekresi insulin terjadi segera setelah stimulus atau rangsangan glukosa yang ditandai dengan meningkatnya kadar glukosa darah, sedangkan sekresi fase kedua terjadi sekitar 20 menit sesudahnya. Pada awal perkembangan DM Tipe 2, sel-sel $\beta$ pancreas menunjukkan gangguan pada sekresi insulin fase pertama, artinya sekresi insulin gagal mengkompensasi resistensi insulin apabila tidak ditangani dengan baik. Pada perkembangan penyakit selanjutnya penderita DM Tipe 2 akan mengalami kerusakan sel-sel $\beta$ pankreas yang terjadi secara progresif, yang seringkali mengakibatkan defisiensi insulin, sehingga akhirnya penderita memerlukan insulin eksogen. Penelitian mutakhir menunjukkan bahwa pada penderita DM Tipe 2 umumnya ditemukan kedua faktor tersebut, yaitu resistensi dan defisiensi insulin. ${ }^{2}$ DM tipe 2 berkaitan 


\section{Review Article}

dengan faktor risiko seperti obesitas, kurang aktivitas (olah raga), usia di atas 40 tahun, konsumsi rokok, dan pola konsumsi makan dan minuman yang tidak sehat. ${ }^{2}$

Diagnosis klinis DM perlu dipertimbangkan apabila terdapat keluhan khas DM berupa poliuria, polidipsia, polifagia, dan penurunan berat badan yang tidak dapat dijelaskan penyebabnya. Apabila terdapat keluhan khas, ditunjang hasil pemeriksaan kadar glukosa darah sewaktu lebih dari $200 \mathrm{mg} / \mathrm{dl}$, maka sudah cukup untuk menegakkan diagnosis DM. Hasil pemeriksaan kadar glukosa darah puasa $>126 \mathrm{mg} / \mathrm{dl}$ juga dapat digunakan sebagai patokan diagnosis DM. ${ }^{1,2,5}$

Penatalaksanaan diabetes mempunyai tujuan akhir untuk menurunkan morbiditas dan mortalitas DM, yang secara spesifik ditujukan untuk mencapai dua target utama, yakni menjaga agar kadar glukosa plasma berada dalam kisaran normal dan mencegah atau meminimalkan kemungkinan terjadinya komplikasi diabetes. ${ }^{1,4,5}$

\section{Tanaman Tapak Dara}

Tumbuhan Tapak Dara berasal dari Amerika tengah. Tapak Dara bisa hidup di tempat terbuka atau terlindung pada bermacam-macam iklim, ditemukan dari dataran rendah sampai ketinggian 800 meter dpl. Tumbuhan Tapak Dara salah satu tumbuhan yang sangat dikenal oleh masyarakat Indonesia. Tumbuhan ini bisa ditemukan di berbagai tempat dengan iklim yang berbeda-beda. Bunga Tapak Dara (Catharanthus roseus (L.) G.Don) memiliki banyak khasiat sebagai obat. Tanaman ini sifatnya parennial, artinya hidup selama kurang lebih dua tahunan ${ }^{16}$

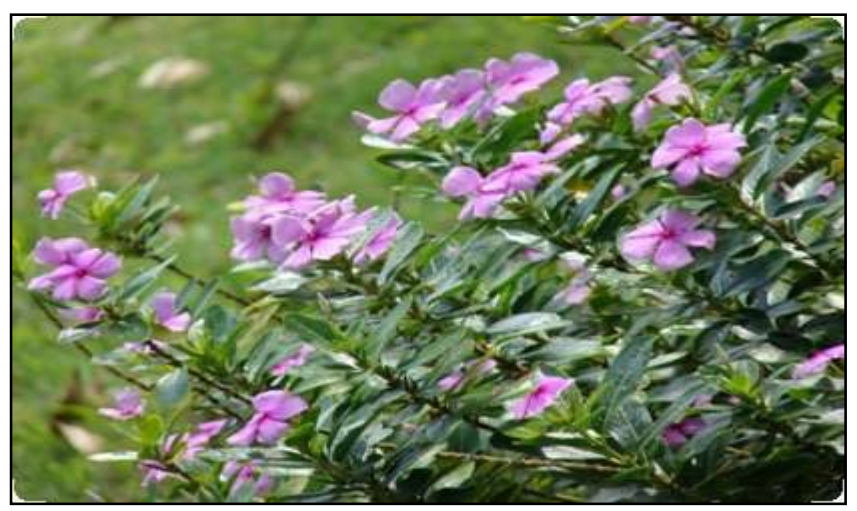

Gambar 1. Tapak Dara (Catharanthus roseus (L.) G. Don). ${ }^{16}$

Berdasarkan pustaka, berikut klasifikasi secara umum dari tumbuhan Tapak Dara (Catharanthus roseus (L.) G. Don) sebagai berikut. ${ }^{16}$

$\begin{array}{ll}\text { Kingdom } & \text { : Plantae } \\ \text { Divisi } & \text { : Magnoliophyta } \\ \text { Kelas } & \text { : Magnoliopsida }\end{array}$


Review Article

$\begin{array}{ll}\text { Ordo } & : \text { Gentianales } \\ \text { Family } & : \text { Apocynaceae } \\ \text { Genus } & : \text { Catharanthus } \\ \text { Spesies } & : \text { Catharanthus roseus (L.) G. Don }\end{array}$

\section{Zat Alkaloid vindolicine}

Secara struktural, Alkaloid vindolicine dikategorikan sebagai alkaloid bisindole. Alkaloid Bisindole adalah heterocycles tetracyclic yang terdiri dari dimer Alkaloid Indole yang dihubungkan oleh ikatan tunggal. Alkaloid Indole, merupakan induk dari banyak turunan alkaloid, yang mempunyai struktur molekul planar dan tersusun atas nitrogen dan karbon. Vindolicine adalah alkaloid tidak biasa yang diisolasi dari Catharanthus roseus dan Catharanthus longifolius dimana strukturnya terdiri dari refleksi dua unit vindoline yang terkondensasi dengan satu fragmen karbon. Umumnya, struktur alkaloid bisindole terbentuk dari gabungan dua unit aspidosperma. Vindolicine adalah satu-satunya turunan alkaloid bisindole yang disusun vindoline. ${ }^{22-25}$

Struktur dari vindolicine dapat diketahui dari beberapa metode pengukuran spectrum. Metode 13C-NMR menunjukkan bahwa struktur space molekul vindolicine tidak simetris. ${ }^{17}$ Ketidaksimetrisan ini menyebabkan beberapa karbon bergeser ke bawah dan ke atas. Metode lainnya adalah metode spectrum $U V .{ }^{18}$ Metode ini membuktikan bahwa vindolicine merupakan turunan alkaloid indole. ${ }^{18}$ Metode berikutnya adalah spectrum IR. Metode ini mengindikasikan adanya hidroksil dan ester pada vindolicine. Dari ke tiga metode di atas, belum dapat disimpulkan vindolicine sebagai alkaloid yang mempunyai struktur. Metode yang mengategorikan vindolicine mempunyai struktur adalah metode mass spectrum. Metode mass spectrum menunjukan terdapat fragmen-fragmen ion vindoline (tiap fragmen mempunyai berat 456). Pada tiap-tiap fragmen, terjadi fusi methylene dari dua nuclei vindoline yang terjadi pada beberapa titik. ${ }^{23}$

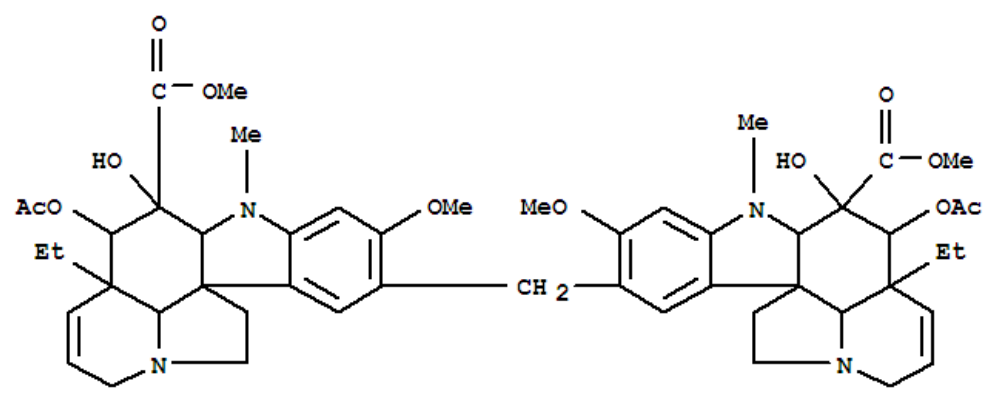

Gambar 2. Struktur Kimia Alkaloid vindolicine. ${ }^{22}$ 
Review Article

\section{Metode Ekstraksi Alkaloid vindolicine dari Daun Tapak Dara}

Tahap pertama yakni daun Tapak Dara yang telah dikeringkan dengan berat $1 \mathrm{Kg}$ dimaserasi dengan $n$-heksana (hex, 10,0 L) selama 3 hari pada suhu kamar $\left( \pm 25^{\circ} \mathrm{C}\right)$. Proses ini diulang sebanyak dua kali. Setelah penghapusan pelarut, selanjutnya ditimbang $100 \mathrm{~g}$ untuk dibasahi dengan $25 \%$ amonia selama satu jam, diikuti dengan merendam dengan diklorometana (DCM). DCM Ekstrak (DE) diperoleh setelah disaring dan dikeringkan pada tekanan rendah. DE diperoleh 42,6 g yang menjadi sasaran untuk ekstraksi asam-basa menggunakan 5\% asam klorida $(\mathrm{HCl})$ dan larutan amonia 25\% untuk mendapatkan 4,2 g minyak mentah alkaloid (DA). DA diolah menjadi sasaran kromatografi kolom (CC) dengan tambahan silika gel 60 (Merck, Darmstadt, Jerman) menggunakan elusi gradien dari DCM (100\%) dan DCM-metanol (95: 5, 90:10, 85:15, 80:20, 75:25, 70:30, 65:35, 60:40, 55:45, 50:50, v/v). Kolom ini kemudian memerah menggunakan DCM-metanol (40:60, 20:80, v/v) dan metanol (100\%). 1 L setiap sistem pelarut yang berbeda digunakan untuk elusi dan hasil dari elusi disebut eluen. Eluen dikumpulkan dalam pecahan $100 \mathrm{~mL}$. Fraksi dengan tipis kromatografi lapis (TLC) profil yang sama kemudian digabungkan. Sebanyak 15 fraksi yang diperoleh (Fraksi 1-15). Untuk mendapatkan zat Alkaloid vindolicine 31,0 mg, fraksi 4 diaplikasikan PTLC dengan hex-etil aseta-aseton $(20: 79: 1, \mathrm{v} / \mathrm{v} / \mathrm{v})$ di bawah uap amonia. ${ }^{22}$ Dengan akhir dari proses fraksi tersebut maka diperoleh Alkaloid vindolicine sebanyak $31 \mathrm{mg} .^{18,26,27}$
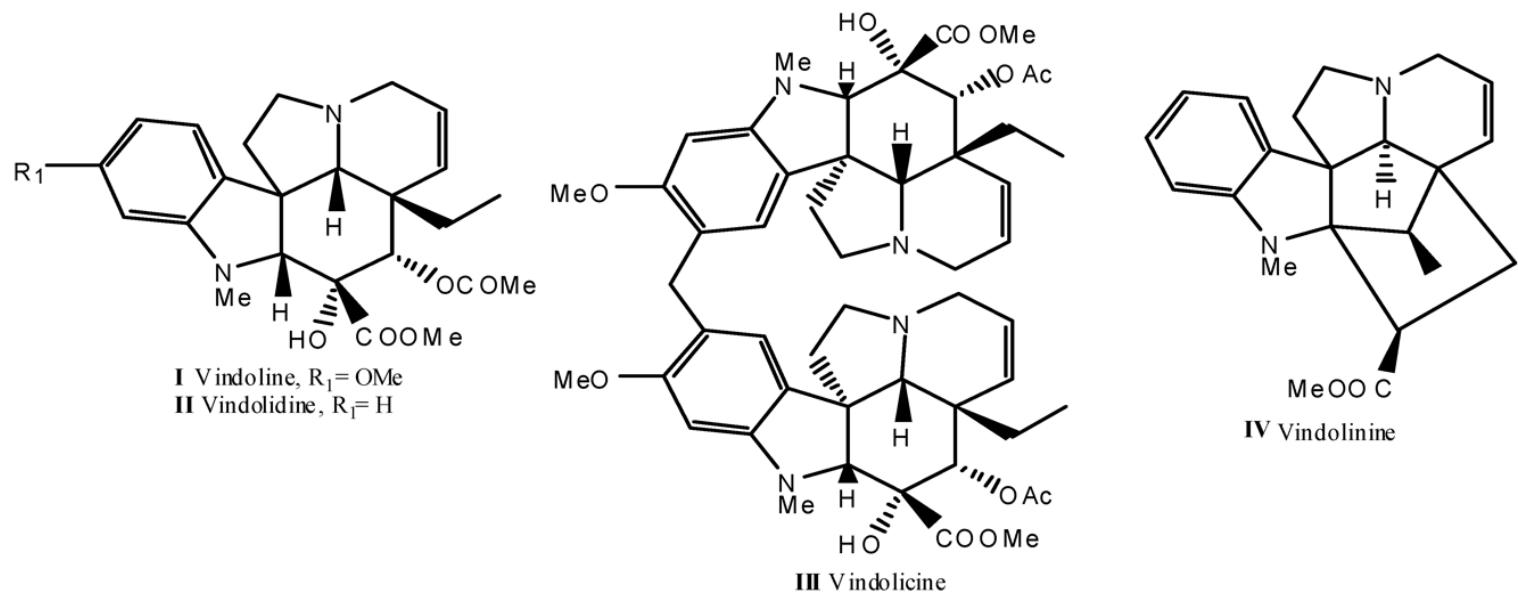

IV Vindolinine

\section{Gambar 3. Struktur Kimia Alkaloid pada Ekstrak Daun Tapak Dara. ${ }^{26}$}

Keterangan:

Struktur kimia alkaloid pada Daun Tapak Dara; (I) vindoline; (II) vindolidine; (III) vindolicine; (IV) vindolinine

\section{Farmakokinetik Akaloid vindolicine}

Zat Alkaloid vindolicine mengalami proses penyerapan di bagian mikrovili yang mana zat tersebut terserap dan beredar di dalam pembuluh darah. Pada saat yang bersamaan penyerapan nutrisi berlangsung. Selama sirkulasi dalam darah yakni target dari Alkaloid 


\section{Review Article}

vindolicine yakni sel $\beta$-TC6 pada pankreas dengan disirkulasi oleh darah, Mekanisme pengenalan sel target oleh zat Alkaloid vindolicine dengan mengaktivasi reseptor G-proint dalam sel langerhans dalam Pankreas. ${ }^{13-18}$ Selain menuju sel target Vindolicine langsung dapat bereaksi dalam pembuluh darah vena dengan menyerap glukosa yang kemudian dibawa ke Hati untuk dibentuk melalui proses glukoneogenesis untuk membentuk Glikogen dan penyimpanan glukosa dalam bentuk glikogen berlangsung juga pada sel-sel otot baik otot skeletal, otot polos, dan bagian myocardium dalam jantung. ${ }^{17-19,22-25}$

\section{Farmakodinamik Akaloid vindolicine}

Zat Alkaloid vindolicine memiliki peranan yakni dalam proses aktivasi reseptor $G$ protein dalam sel $\beta$-TC6 pada pankreas. ${ }^{13}$ Jika terdapat penurunan insulin sel $\beta$-TC6 akan menginduksi G-protein dan membuka kanal sel $\beta$-TC6 untuk proses transportasi zat alkaloid vindolicine ke dalam sel kemudian terjadi sintesis oleh sitosol dalam sel $\beta$-TC6 untuk mempengaruhi pengeluaran insulin untuk menurunkan kadar glukosa dalam darah. ${ }^{13,18,29}$

Aktivitas cytotoxic alkaloid vindolicine terhadap sel $\beta$ pankreas yang telah diuji melalui uji MTT (sitotoksik 3-(4,5-dimetilazol-2-il)-2,5-difeniltetrazolium bromide). ${ }^{30,31}$ Berdasarkan hasil uji MTT diketahui bahwa IC50 dalam zat vindolicine adalah $68.0 \pm 10.4 \mu \mathrm{g} / \mathrm{mL}$ atau 73.5 $\pm 11.3 \mu \mathrm{M}$. Pengaruh pada sel $\beta$-TC6 yakni zat Alkaloid vindolicine aman digunakan pada dosis $12,5 \mathrm{mg} / \mathrm{ml}$ dan lima kali lebih tidak beracun daripada doxorubicin. Berdasarkan dosis tersebut, alkaloid vindolicine dapat menurunkan kadar glukosa darah sebesar $\pm 50-100 \mathrm{mg} / \mathrm{dl}$ bagi penderita diabetes dengan kadar glukosa di atas $140 \mathrm{mg} / \mathrm{dl} .{ }^{13}$ Sel target yang menjadi sasaran dari zat alkaloid vindolicine selain berpengaruh dalam mengaktivasi sel $\beta$-TC6 pankreas juga mempengaruhi pengaturan kadar gula darah dalam tubuh yakni dengan menjaga homeostasis dalam tubuh. ${ }^{13,31-33}$ Peningkatan penyerapan glukosa di sel otot bisa memperbaiki kondisi hiperglikemia diabetes tipe 2. Alkaloid vindolicine menurunkan gula darah lebih besar dari insulin maupun alkaloid-alkaloid lain yang terkandung dalam Catharanthus roseus. Penurunan glukosa oleh Alkaloid vindolicine tiga kali lebih tinggi dibanding yang tidak mendapat perawatan. Berikut grafik tingkat pengaruh zat alkaloid vindolicine (III) sebagai berikut. ${ }^{13}$ 
Review Article

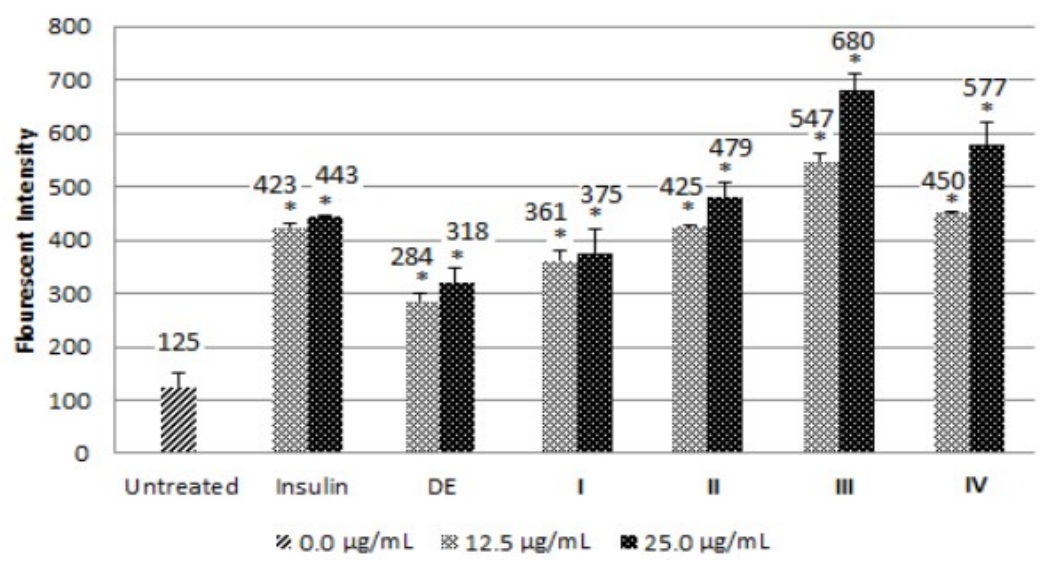

Gambar 4. Pengaruh Alkaloid vindolicine (III) dalam memacu aktivasi sel $\beta$-TC6 dalam menurunkan kadar glukosa. ${ }^{13}$

(DE) dichloromethane extract; (I) vindoline; (II) vindolidine; (III) vindolicine; (IV) vindolinine.

Zat alkaloid vindolicine menunjukkan penyerapan glukosa tertinggi di sel $\beta$-TC6. Dibandingkan dengan standarnya yaitu insulin, vindolicine lebih efektif $65,14 \%$ dalam penyerapan kadar glukosa dalam darah. Pengaruh dosis terapi dari hasil ekstraksi zat alkaloid vindolicine dari daun tapak dara tidak signifikan menimbulkan efek toksik. ${ }^{32-35}$

Berdasarkan penjelasan penelitian sebelumnya diperoleh potensi yang menjanjikan dari zat alkaloid vindolicine ini, efek antiglikemik yang baik dapat ditawarkan dari daun Tapak Dara ini. Akan tetapi belum terdapat penelitian yang membahas perbandingan efek antiglikemik dari zat aktif ini dengan obat diabetes konvensional. Maka dengan demikian, diperlukan penelitian lebih lanjut untuk memaksimalkan potensi dari ekstrak daun Tapak Dara ini sehingga dapat menjadi inovasi dalam terapi terbarukan dengan tingkat efisiensi dan efektivitas yang lebih baik dari obat konvensional ataupun dapat menjadi obat yang bersifat komplementer bagi pasien diabetes. Hal ini juga dapat menjadi terobosan untuk mengurangi kejadian komplikasi dari penyakit diabetes.

\section{Simpulan}

Berdasarkan telaah pustaka maka disimpulkan bahwa alkaloid vindolicine dalam daun Tapak Dara (Catharanthus roseus (L.) G. Don) memiliki potensi yang baik sebagai terapi bagi pasien diabetes, namun masih diperlukan penelitian lebih lanjut untuk membuktikan efektivitas dan efisiensi dari pemanfaatan zat aktif dari ekstrak daun Tapak Dara dibandingkan dengan penggunaan obat diabetes konvensional. 


\section{Review Article}

\section{Daftar Pustaka}

1. WHO Department of Noncommunicable Disease Surveillance Geneva. Definition, Diagnosis and Classification of DM and its Complications. Report of a WHO Consultation Part 1: Diagnosis and Classification of DM. 2014; 56: 32-36.

2. Trisnawati S, Widarsa T, Suastika K. Faktor risiko diabetes mellitus tipe 2 pasien rawat jalan di Puskesmas Wilayah Kecamatan Denpasar Selatan. Udayana University; 2013. Repository.

3. Satyarsa AB, Suryantari SA, Gumilang PG, Dewi NN. Potensi FuMA stem cells, kombinasi fukoidan dan Bone Marrow Stem Cells (BMSCs), sebagai penatalaksanaan mutakhir pada Infark Miokard Akut. Intisari Sains Medis. 2019; 10(1): 174-180.

4. Suastika K, Dwipayana P, Saraswati IM, Gotera W, Budhiarta AA, Sutanegara IN, Gunadi IG, Nadha KB, Wita W, Rina K, Santoso A. Prevalence of obesity, metabolic syndrome, impaired fasting glycemia, and diabetes in selected villages of Bali, Indonesia. Journal of the ASEAN Federation of Endocrine Societies. 2014; 26(2):159.

5. Letchuman GR, Wan Nazaimoon WM, Wan Mohamad WB, Chandran LR, Tee GH, Jamaiyah H, et al. Prevalence of diabetes in the Malaysian national health morbidity survey III 2006. Med J Malaysia. 2010; 65(3):180-6.

6. Rammohan M. Effect of ethanolic extracts of Andrographis paniculata on type 2 diabetes mellitus and insulin resistant rats [PhD dissertation]. University Sains Malaysia. 2009.

7. Patel DK, Kumar R, Laloo D, Hemalatha S. Natural medicines from plant source used for therapy of diabetes mellitus: An overview of its pharmacological aspects. Asian Pacific Journal of Tropical Disease. 2012; 2(3):23950 .

8. Nugroho AE, Lindawati NY, Herlyanti K, Widyastuti L, Pramono S. Anti-diabetic effect of a combination of andrographolide-enriched extract of A. paniculata and asiaticoside-enriched extract of Centella asiatica L. in high-fructose-fat-fed rats. Indian J Exp Biol. 2013; 51:1101-8.

9. Odeyemi S, Bradley G. Medicinal Plants Used for the Traditional Management of Diabetes in the Eastern Cape, South Africa. Molecules. 2018; 23(11):2759.

10. Ferreres F, Pereira DM, Valentão P, Andrade PB, Seabra RM, Sottomayor M. New phenolic compounds and antioxidant potential of Catharanthus roseus. J Agric Food Chem. 2008; 56(21):9967-74.

11. Ohadoma SC, Michael HU. Effects of co-administration of methanol leaf extract of Catharanthus roseus on the hypoglycemic activity of metformin and glibenclamide in rats. Asian Pacific J Trop Med. 2011; 4(6):475-7.

12. Tahrani AA, Barnett AH, Bailey CJ. Pharmacology and therapeutic implications of current drugs for type 2 diabetes mellitus. Nature Rev Endocrinol. 2016; 12(10):566.

13. Arya A, Looi CY, Cheah SC, Mustafa MR, Mohd MA. Anti-diabetic effects of Centratherum anthelminticum seeds methanolic fraction on pancreatic cells, $\beta$-TC6 and its alleviating role in type 2 diabetic rats. J Ethnopharmacol. 2012; 144(1):22-32.

14. Chauhan PK, Pandey IP, Dhatwalia VK, Singh V. Anti-diabetic effect of ethanolic and methanolic leaves extract of Centella asiatica on alloxan induced diabetic rats. Int J Pharm Bio Sci. 2010; 1(2).

15. Teoh SL, Das S. Phytochemicals and their effective role in the treatment of diabetes mellitus: a short review. Phytochem Rev. 2018; 17(5):1111-28.

16. Rasineni K, Bellamkonda R, Singareddy SR, Desireddy S. Antihyperglycemic activity of Catharanthus roseus leaf powder in streptozotocin-induced diabetic rats. Pharmacognosy Res. 2010; 2(3):195.

17. Rasineni K, Gujjala S, Sagree S, Putakala M, Bongu SB, Bellamkonda R, Singareddy SR, Desireddy S. Therapeutic Efficacy of Catharanthus roseus in Type 1 and Type 2 Diabetes Mellitus in Wistar Rats. Springer. 2017; 201-246.

18. Tiong SH, Looi CY, Arya A, Wong WF, Hazni H, Mustafa MR, et al. Vindogentianine, a hypoglycemic alkaloid from Catharanthus roseus (L.) G. Don (Apocynaceae). Fitoterapia. 2015; 102:182-8.

19. Nisar A, Mamat AS, Hatim MI, Aslam MS, Syarhabil M. An updated review on Catharanthus roseus: phytochemical and pharmacological analysis. Ind Res J Pharm Sci. 2016; 3:632-53.

20. Barkat MA, Abul H, Rahman MA. Agricultural, pharmaceutical, and therapeutic interior of Catharanthus roseus (L.) G. Don. Springer. 2017;71-100.

21. Renjini KR, Gopakumar G, Latha MS. The Medicinal Properties of Phytochemicals in Catharanthus roseus-A Review. European J Pharm Med Res. 2017;4(11):545-51.

22. Tiong S, Looi C, Hazni H, Arya A, Paydar M, Wong W, et al. Antidiabetic and antioxidant properties of alkaloids from Catharanthus roseus (L.) G. Don. Molecules. 2013;18(8):9770-84.

23. Barrales-Cureño HJ, Andrade-Hoyos P, Reyes CR, Espinoza-Perez J, Valdez LG, De Jesús AG, et al. Alkaloids of Pharmacological Importance in Catharanthus roseus. Alkaloids. 2019. DOI: 10.5772/intechopen.82006

24. Almagro L, Fernández-Pérez F, Pedreño M. Indole alkaloids from Catharanthus roseus: bioproduction and their effect on human health. Molecules. 2015;20(2):2973-3000.

25. Senbagalakshmi P, Rao MV, Kumar TS. In vitro studies, biosynthesis of secondary metabolites and pharmacological utility of Catharanthus roseus (L.) G. Don: a review. Springer. 2017;153-99.

26. Schweizer F, Colinas M, Pollier J, Van Moerkercke A, Bossche RV, De Clercq R, et al. An engineered combinatorial module of transcription factors boosts production of monoterpenoid indole alkaloids in Catharanthus roseus. Metabolic engineering. 2018; 48:150-62. 


\section{Review Article}

27. Alam F, Shafique Z, Amjad ST, Bin Asad MH. Enzymes inhibitors from natural sources with antidiabetic activity: A review. Phytotherapy Research. 2019;33(1):41-54.

28. Das S, Sharangi AB. Madagascar periwinkle (Catharanthus roseus (L.) G. Don): Diverse medicinal and therapeutic benefits to humankind. J Pharmacog Phytochem. 2017;6(5):1695-701.

29. Pham HN, Vuong QV, Bowyer MC, Scarlett CJ. Effect of extraction solvents and thermal drying methods on bioactive compounds and antioxidant properties of Catharanthus roseus (L.) G. Don (Patricia White cultivar). J Food Proc Pres. 2017 Oct;41(5):e13199.

30. McGaw LJ, Prinsloo G, Street RA. Alkaloids: Potential Health Benefits and Toxicity. In Utilisation of Bioactive Compounds from Agricultural and Food Production Waste 2017 Sep 7 (pp. 68-93). CRC Press.

31. Street RA, Prinsloo G, McGaw LJ. Alkaloids potential health Benefits and toxicity. InVuong Utilisation of Bioactive Compounds from Agricultural and Food Production Waste 2017 Sep 7. Taylor \& Francis Group.

32. Macáková K, Afonso R, Saso L, Mladěnka P. The influence of alkaloids on oxidative stress and related signaling pathways. Free Radical Biology and Medicine. 2019.

33. Satyarsa ABS. Potential of Fucoidan From Brown Seaweeds (Sargassum sp.) as Innovation Therapy on Breast Cancer. J Med Health. 2019; 2(3): 909-919.

34. Mishra MR, Srivastava RK, Akhtar N. Enhanced Alkaloid Production from Cell Culture System of Catharanthus Roseus in Combined Effect of Nutrient Salts, Sucrose and Plant Growth Regulators. J Biotech Biomed Sci. 2018;1(4):14.

35. Dey A, Mukherjee A, Chaudhury M. Alkaloids from apocynaceae: origin, pharmacotherapeutic properties, and structure-activity studies. In Studies in Natural Products Chemistry. Elsevier. 2017; 52: 373-488. 